\begin{tabular}{ll}
\hline 臨 & 床 \\
\hline
\end{tabular}

\title{
心因性難聴児の心理療法
}

\author{
芦谷 道子・井野千代徳

\section{Psychotherapy for Psychogenic Hearing Loss}

\author{
Michiko Ashitani and Chiyonori Ino \\ (Kansai University of Medical Science)
}

The cases of 31 patients with psychogenic hearing loss who visited us between 2000 and 2002 were reviewed.

The patient group included 9 males and 22 females. The age range was 6 to 14 years, with a mean age of 9.1 years. We classified the patients into three groups, Other-oriented group, Self-oriented group and Conflict group, based on psychological interview and tests. Then we reported sand play and psychological feature of each group.

In the Other-oriented group, the symptoms are considered to represent "protection" against the incursion of others, and it is desirable to cultivate a sense of identity in psychotherapy. In the Self-oriented group, the symptoms may mean "refusal" of others who attack them, and it is necessary to treat both the factor-problems and the secondary mental problems. In the Conflict group, the symptoms can be considered to represent "demand" for care, and it is desirable to encourage self-expression in receptive psychotherapy. The clinical presentation of psychogenic hearing loss varies, and individualized mental assistance is essential.

Key words : psychotherapy, psychogenic healing loss, sand play

はじめに

われわれは, 大学病院耳鼻咽喉科に附属の心理相談室 を設け，医師と臨床心理士が連携しつつ心因性難聴児の 心理治療に取り組んでいる. 心因性難聴とは, 「器質性の みの障害と考えにくい聴こえの状態」1) と定義され，患 者の示す病態像は単一ではないことがこれまでに示唆さ れている2).われわれの経験からも, 多様な病態像に応 じたきめ細かな心理的援助の必要性を感じている。本論 文に㧍いて，患者の対人関係様式より，心因性難聴児を 大きく 3 群に分類する. そして, 各群にみられた病態像, 箱庭の特徵を報告し, 心理的特徵, 望をしい心理療法の あり方について, 臨床心理士の立場から考察したい.

\section{対象}

平成 12 年 5 月から平成 14 年 7 月までの期間に, 関西 医大附属香里病院耳鼻咽喉科にて心因性難聴々診断さ れ, 当科附属心理相談室に心理療法を依頼された患者 31 名を対象とした. 対象者の内訳は, 男子 9 名, 女子 22 名 で，これまでの報告どおり女子に多く，年齢は 6 ～14 歳 で平均 9.1 歳（土2.48）であった。

\section{方法}

1. 診断・治療形態

心因性難聴の診断は, 純音聴力検査と他覚的聴力検査 (聴性脳幹反応 : $\mathrm{ABR}$ ) との結果の間に $25 \mathrm{~dB}$ 以上の差が 
みられたことにより確定した．紹介されてきた患者に心 理面接を行い, 生育歴, 現症歴および家族歴を聴取した。 必要に応じて描画などによる心理テストや知能テストを 実施し，箱庭を作製してもらった，以上の結果を踏まえ て心理的な見立て（治療方法や治療目標を含んだ総合的 な診断）を行い，本人および家族の意思を尊重しつつ， 個々の事例において，最も適切であると思われる心理的 サポートのあり方を選択した．原則として，初回面接に は 2 時間, 継続面接には 50 分の時間が確保されており, 面接の頻度は週に 1 度から月に 1 度と, 事例によりさま ざまである．面接の方法としては，カウンセリングのほ か, 箱庭や描画を用いた遊戯療法が随時選択された。

2. 患者の分類

今回は，母親を中心とする他者と患者との対人関係様 式からの分類を試みた．具体的には，患者が自己と他者 の思いのどちらを優先させる傾向にあるか，すなわち， 自己の意志と他者からの要請との間に, 患者がどのよう なバランスをとっているかといらことに着目し，その視 点より患者を大きく 3 群に分類した. まず 1 群目は, 自 己の意志を抑え,他者の思いを優先させる傾向にある「他 者優先群」である. この群は, 自律性・主体性に欠け, 他者の要請のままに他律的に行動しょうとする特徴を持 つ. 2 群目は, 他者よりも自己の意志を優先する傾向に ある「自己優先群」である，この群は，他者の思いを汲 み取ることが苦手であり，状況をわきまえずに自分の関 心の赴くままに行動しがちであるといら特徵がある. 3 群目は, 自己の意思と他者からの要請との間に葛藤が起 こり, 表面的・意識的には他者の思いを尊重しょうと努 めつつ，無意識的に身体が自己の欲求を代弁する傾向に ある「葛藤群」である。この群は基本的に愛情や注目が 不足しているにもかかわらず，それを直接欲求できず， 症状に転換して他者の関心を得ようとする特徴がある.

分類を施したのは主に臨床心理士で，心理面接，心理 テストなどを基にして, 各々の患者の対人的関係様式が どの群に合致するかを判断し分類した。 その際，必要に 応じて耳鼻咽喉科医師，小児科医師，精神科医師の意見 を参考にした。

本論文での分類は，渡辺ら ${ }^{3)}$ の提示した 3 分類にほぼ 相当するものであると思われる. 渡辺ら ${ }^{3)}$ は, ロール シャッハテストを中心とした心理検査を基にして, 適応 の視点から本疾患を 3 群に分類している．すなわち，心 身症的性格の「過適応群」, 社会的に未熟である「前適応
群」, 転換ヒステリ一的性格の「不適応群」の 3 群であ り，それぞれわれわれの分類による「他者優先群」「自己 優先群」「葛藤群」にほぼ相当すると考えられる。しか し，われわれの経験した事例においては，各群の適応の レベルはさまざまであり, 例えば「他者優先群」の不適 応事例, 「自己優先群」「暮藤群」の適応事例がみられた。 そこで今回は, 対人関係様式を中心とした分類を試みた。

\section{結 果}

1. 年齢および性別（表 1）

31 名の患者のうち,「他者優先群」に属したのは，11 名 (35.4\%) で，女子のみという特徴があり，年齢は平 均 9.0 歳（土2.14）であった.「自己優先群」に属した のは 10 名 (32.3\%) であり，そのうち男子が 7 名（70 \%) で，他群に比し男子が多いという特徴があった．年 齢は平均 8.8 歳（土2.53）であった。「葛藤群」は 10 名 (32.3\%) であり，そのうち 8 名 (80\%) が女子で，年齢 は平均 9.4 歳（土2.95）であった.

\section{2. 各群の病態像 (表 2)}

「他者優先群」の患者は, 半数以上が難聴を自覚してお らず，また表面的には心理的問題が感じられない事例が 多いため, 親子ともども心理療法に対しては消極的で あった。臨床像としては, 全事例に緊張の強さが感じら れ，内閉的・室黙的な印象を受けるタイプと，優等生で 過適応的なタイプとが観察された。 また随伴症状として, 繰り返す中耳炎, 軽度難聴など, 耳に器質的な弱さがあ る事例が 6 例 (55\%) あり, 他群より多い傾向にあった。 家庭環境は過保護的, 過干渉的である事例が多く, 小さ い頃から手が掛からず，親にとってやりやすい「いい子」 であったと述懐されることが多かった。 そして，心理面 接を重祆るとほほとんどの事例で友人関係の問題が明ら かになり，休み時間のみ保健室で過ごす事例，障害児の 世話という役割でどうにか自分の居場所を得ていたとい

表 1 各群の性別・年齢分布

\begin{tabular}{c|c|c|c|c|c}
\hline \hline \multicolumn{2}{l|}{} & 他者優先群 & 自己優先群 & 葛藤群 & 計 \\
\hline 性 & 男 & 0 & 7 & 2 & 9 \\
別 & 女 & 11 & 3 & 8 & 22 \\
\hline \multirow{3}{*}{ 年 } & $6 \sim 8$ & 5 & 7 & 4 & 16 \\
齢 & $9 \sim 11$ & 4 & 0 & 3 & 7 \\
& $12 \sim 14$ & 2 & 3 & 3 & 8 \\
\hline \multicolumn{2}{|c|}{ 計 } & 11 & 10 & 10 & 31
\end{tabular}


表 2 各群の病態像

\begin{tabular}{|c|c|c|c|}
\hline 病像群 & 他者優先群 & 自己優先群 & 葛藤群 \\
\hline 難聴自覚（\%） & $45 \%$ & $80 \%$ & $100 \%$ \\
\hline 心理療法への取組み & 消極的 & 積極的 & 積極的 \\
\hline 臨床像 & $\begin{array}{l}\text { 緊張が強い } \\
\text { 閉的 優等生的 }\end{array}$ & $\begin{array}{l}\text { 注意集中困難 } \\
\text { 落ち着きがい } \\
\text { 無・劣等感 }\end{array}$ & $\begin{array}{l}\text { 注目欲求強い } \\
\text { 誇張的訴え }\end{array}$ \\
\hline $\begin{array}{c}\text { 随伴症状 } \\
\text { （他群より多い傾向のもの） }\end{array}$ & 器質的耳疾患 & $\begin{array}{l}\text { 脳波異常・チック } \\
\text { 夜不眠 }\end{array}$ & 心因性視覚障害 \\
\hline 家庭環境 & 過保護・過干渉的 & $\begin{array}{l}\text { 䦓題児扱い } \\
\text { 親の批判的態度 }\end{array}$ & $\begin{array}{l}\text { 雨親離婚 } \\
\text { 家庭不和 } \\
\text { 藽不在 }\end{array}$ \\
\hline 学校環境 & 友人関係に問題 & $\begin{array}{l}\text { 友人とのトラブル } \\
\text { 集団行動になじめず }\end{array}$ & $\begin{array}{l}\text { 友人と登校 } \\
\text { 不 }\end{array}$ \\
\hline 予後（難聴） & $\begin{array}{l}\text { 治癒 }(67 \%) \\
\text { 改善 }(33 \%) \\
\text { 不変 }(0 \%)\end{array}$ & $\begin{array}{l}\text { 治癒 }(57 \%) \\
\text { 改善 }(29 \%) \\
\text { 不変 }(14 \%)\end{array}$ & $\begin{array}{l}\text { 治癒 }(22 \%) \\
\text { 改善 }(56 \%) \\
\text { 不変 }(22 \%)\end{array}$ \\
\hline 予後（心理的問題の改善率） & $100 \%$ & $71 \%$ & $78 \%$ \\
\hline
\end{tabular}

う事例，随分治療が進んでから泣きながら友人関係の悩 みを訴えた事例等があった。予後については， $25 \mathrm{~dB}$ 以 下を治瘑， $30 \mathrm{~dB}$ 以上変動したものを改善，それ以外を 不変として判定したところ (以下同じ), この群では, 中 断, 経過観察中の事例が 8 例と多く, 半年以上心理治療 を継続した 3 例についてのみ予後をみると， 2 例が治癒， 1 例が改善であった。 またその 3 例においては，何らか の心理的問題の改善もみられた。

「自己優先群」では，80\%の事例で難聴を自覚してお り，患者も家族も心理的援助を求める思いが強く，心理 療法に対しては積極的であった。臨床像としては, 注意 集中の困難, 落ち着きのなさ, 衝動性が目立って観察さ れた。 ほかにも手先が不器用で片づけが苦手, 忘れ物や 落し物が多いなどの問題を抱えており，ADHD（注意欠 陷多動性障害)，LD（学習障害）と診断される事例吕多 かった。また随伴症状として，脳波異常，チック，夜尿， 睡眠時驚愕・遊行症，不眠など，より器質的な要因が大 きいと思われる問題を併発しており，その素因に基づく さまざまな 2 次的心理的問題を抱えていた，多くは対人 関係上の問題で,「いじめられている」という被害感を持 ちやすく，他者に対する拒絶感や攻撃性が高い，無力感 や絶望感，劣等感が強 $<，$ 行動化（放火，盗廦等）の問 題, 幻覚様の症状を抱えるケースもあった。 また，家庭・ 学校両環境において患者は問題児扱いされており，他者 からの批判にさらされることが多かった．特に母親は患 者への対応に困惑し, 疲弊しており，患者は幼少時から
やりにくい子であったと述懐されることが多い，学校に おいては，友人とのトラブルが多く，集団行動が困難で あった，予後については，半年以上心理療法を継続した 7 例のうち，4 例 (57\%) が治癒，2 例 (29\%) が改善, 1 例（14\%）が不変であった。 また 5 例（71\%）の患者 に何らかの心理的問題の改善もみられた。

「葛藤群」の患者は，全例において難聴を自覚し，その 訴えは切実であった。親子ともども自分達の心理的問題 にどこか気付いており，心理療法を導入すると，むしろ 安堵する様子で，積極的に治療に臨むケースがほとんど であった。臨床像としては，注目欲求が強く，心理療法 の場で能動的に自己表現・自己開示をし，それが治療者 に受容される経験に大きな意味を見出すようであった。 随伴症状として, 心因性視覚障害を併発するケースが全 体の $36.4 \%$ にみられ，この群の難聴は，広く感覚器官の ヒステリー症状の一部として捉えらるものと考えられ た. 家庭環境として，36.4\%に両親の離婚がみられ，家 庭不和，母親不在など，家庭に問題のあるケースが多く， その不安定な家庭のなかで, 多くの患者は家族, 特に母 親の支え役となっていた。学校においても，いじめや友 人関係のトラブル，不登校などの問題が顕在化している 事例が多かった。難聴になるきっかけがはっきりしてお り(例えばいじめなど), 家庭的問題が深刻でないケース では予後は良好であった。半年以上心理療法を継続した 9 例のうち，2 例 (22\%) が治癒，5 例 $(56 \%)$ が改善， 2 例（22\%）が不変であった。 また 7 例（78\%）の患者 
には，何らかの心理的問題の改善むみられた。しかし症 状は患者の周囲の人間関係や治療者との関係に影響を受 け，変動しやすく，他の転換ヒステリー症状を併発しや すいといら特徴むみられた。

3. 各群の箱庭の特徵

「他者優先群」の箱庭は，「悪者のいない平和な国」「い い人ばかりの理想の世界」との患者の言葉にみられるよ らに，美しい善なる世界の表現が多く，一見何の危機む 感じない。しかしそこには, 強固な柵が張り巡らされ（図 1 左)，見張り役の警察やパトカーが多用されるなど，防

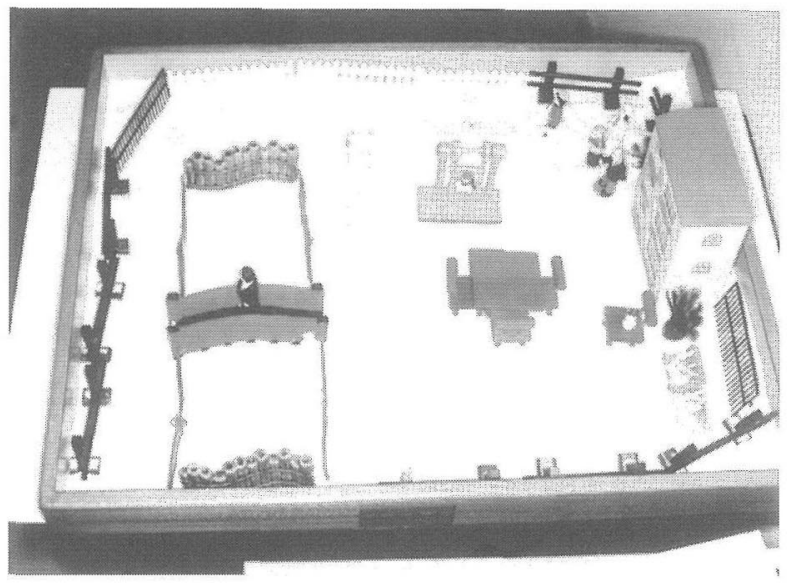

衛性と閉鎖性が感じられ，自分の世界を守るためにかな りのエネルギーを費やしている患者像が浮かび上がる。 また置かれるアイテム数む少なく, 静的で, 子どもらし い躍動感に欠けている (図 1 右)。そして治療が進むにつ れ，徐々に攻撃的なもの，気味の悪いもの，悪者などの 陰性の要素を導入する傾向にあり, 表現が生命力に満ち てくるという印象を受けた。

「自己優先群」の箱庭では，天災による破壊，恐竜や猛 獣による攻撃 (図 2 左), 多数による単一の対象への攻撃 (図 2 右)など, 圧倒的な強弱関係における破壊や戦いが,

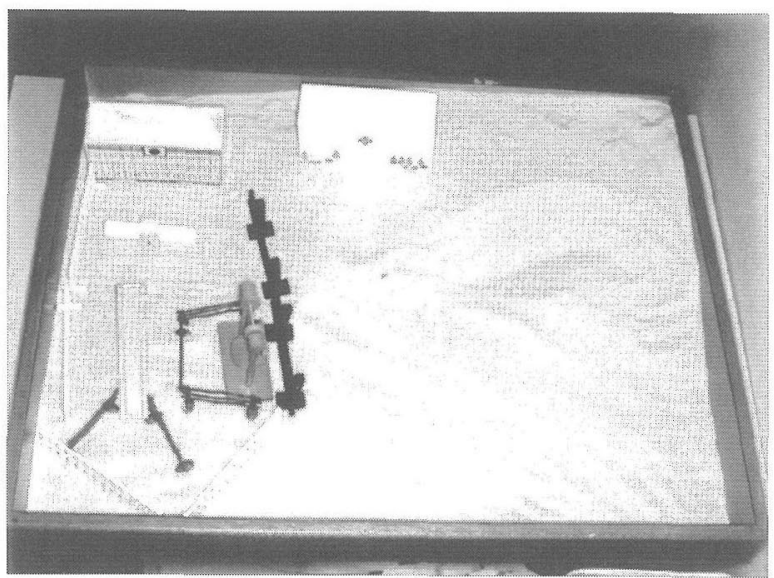

図 1 他者優先群の箱庭

一見何の危機も感じないが，そこには頑固な栦が張り巡らされ（左），防衛性と閉鎖性が感じられる。また置かれたアイテム数 も少なく, 静的で子どもらしい躍動感に欠ける(右)。
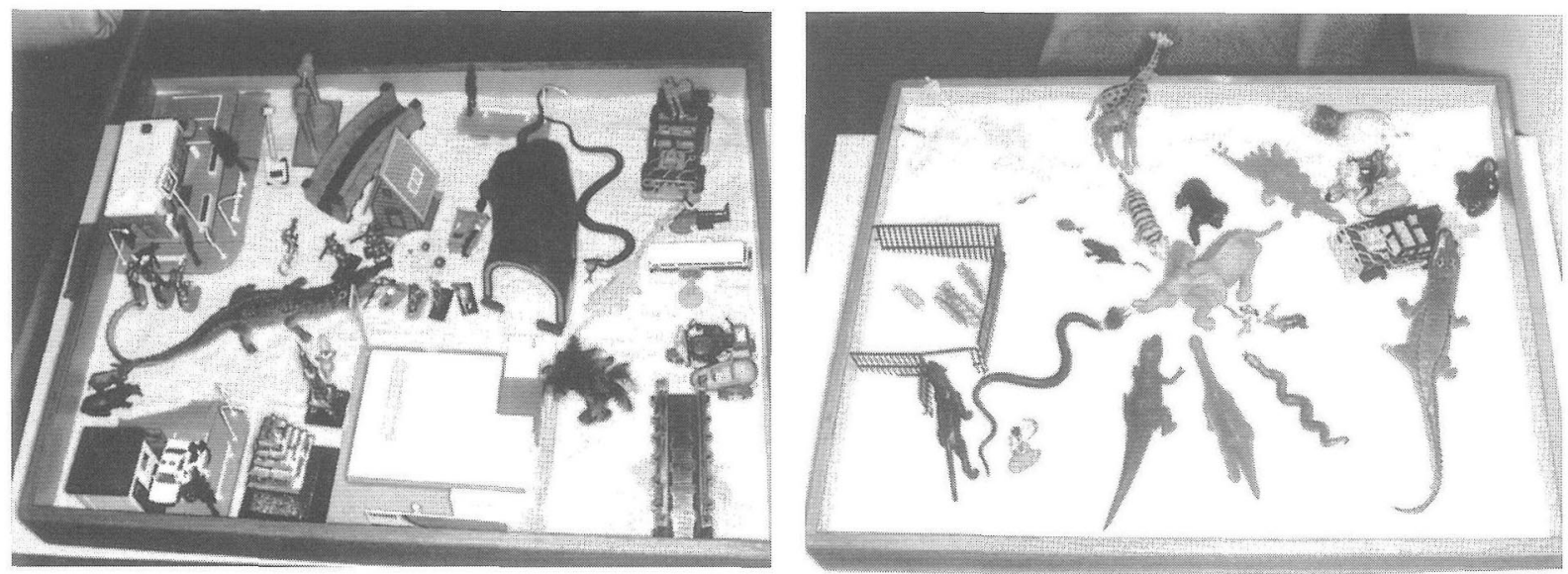

図 2 自己優先群の箱庭

天災による破壊，恐竜や猛獣による攻撃（左），多数による単一の対象への攻撃（右）など, 強弱関係における破壊や戦いが表 現される。 

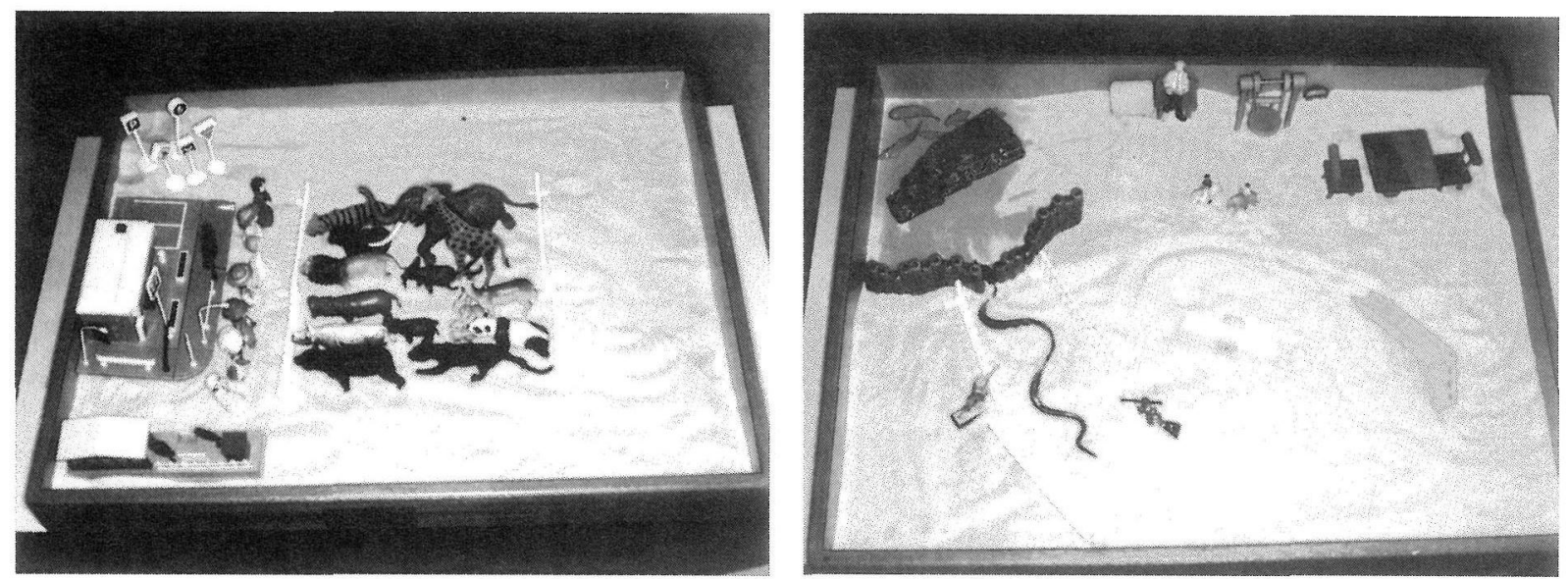

図 3 葛藤群の箱庭

緩やかな柵で猛獣と対峙している少女達（左），無防備に泳ぐ魚達をひそかに狙ら大蛇（右）など，患者の無防備さと，ひそか に迫る危機的状況が伺われる。

生々しくエネルギッシュに表現される。弱者は徹底的に 痛めつけられ，圧倒的な破壊力の前に，無力な患者像が 浮かび上がる，治療が進むにつれ，無力であったものが 力をつけ，穏やかなをとまりある世界を構築できるよう になる傾向があった，また，砂そのものの感触を味わう 原初的な遊びも多くなされ，心理治療の場に㧍いて，自 らの根底を作り直す作業が進められているという印象を 受けることが多かった。

「葛藤群」の箱庭では, 蛇や猛獣などの恐ろしく不気味 なものが，日常のなかにそっと潜んでいるような場面が 表現され, 不安や恐怖の顕現が感じられた。例えば, 緩 やかな梱で猛獣と対峙している少女達 (図 3 左), 無防備 に泳ぐ魚達をひそかに狙ら大蛇（図 3 右）など，守りの 薄さを表現したイメージの箱庭が多く, 患者の無防備さ と，ひそかに迫る危機的状況が伺われる，そこから，自 分の危機的状況に気付いてほしいという患者のメッセー ジが感じられた。治療が進むにつれ，守りの要素が強化 され,より安定した表現へと変化していく傾向にあった。

\section{考察}

以上の結果を踏まえ，各群それぞれの心理的特徴およ び望ましい心理療法のあり方について考察する。

まず「他者優先群」の心理的特徴について考えてみた い. この群の患者は緊張が強く受身的で, 好きなむのや やりたいことなどを尋ねても困惑することが多く, 主体 性が未熟であると考えられる。患者らは子供よりも大人
の原理に親和性を抱いており，大人によって統制された 他律的な時空間に，より安定を得るようであった。子ど もの世界のなかで独特の生きにくさを感じている患者に とって，子ども同士が群れをなし，大人とは違った子ど もの世界の法則ができ始める前思春期という時期は，危 機的状況となりやすいものと考えられる．またこの群の 患者は，大人の心身症患者によくみられるアレキシシミ ア (失感情症) 的傾向を持ち, 特に自分の陰性感情を意 識化することが不得手であるといら特峚があった。箱庭 からも理解できるように，患者は善なる母子一体的世界 を希求する傾向が強いように見受けられる，彼らは，他 者のいらことを「聞き」すぎる耳を持っているゆえ，こ れ以上他者吕侵入してくるのを防ぐために，身体が難聴 といらサインを出しているのではないかとわれわれには 思われる。症状は, 箱庭に張り巡らされた柵のよらに, 外の世界からの「守り」の意味を持っているのではない だらうか。

したがってこの群の患者には，守られた心理治療の場 において主体性が尊重される体験が重要となる．患者は 警戒心が強く，心理療法の場そのものが脅威的になりや すいので, 不安を与えない適度な枠をこちらが示しつつ, 徐々に患者の主体性を育んでいくことが求められる。彼 らの心理的問題は周囲加ら気付かれにくいが，近年，心 身症と人格障害が心理的構造において類似していると指 摘されており，患者の身体のSOS サインを受け止めるこ とが望まれる。しかし，難聴の自覚がなく心理的閣題が 
顕在化していない事例では, 心理療法の導入が難しく, また時期の見合わない心理療法は副作用が大きいことも あって, 今現在, 患者とその家族がどのような心理的援 助を必要としているかの見極めが重要となる.

「自己優先群」の患者は, 他者から否定的な言葉を浴び せられる経験を重悋てきており，それらの言葉を「もう これ以上聴きたくない」と感じている. 患者にとって症 状は，「拒絶」としての意味を持つと考えられる.

彼らへの心理援助においてまず重要なのは, 他機関(小 児科, 精神科, 学校, 他の療育機関等）との連携によっ て，素因的問題をケアすることである. 特に ADHD との 関連には注意が必要で，小児科による薬物療法を開始す ると, 聴力が著しく改善した例もあった. 患者および家 族による症状の理解と受容, 患者に対する周囲からの批 判姿勢の緩和が治療の重要な要因となる，心理治療の場 においては, 2 次的な心理的問題への対応が求められ, 患 者の傷つきや攻撃性を受け止め, 承認・成功体験を重ね るなかで患者の自己像の回復を目指していくことにな る. 発達的視点に基づく息の長い心理援助が望まれる. ADHD に関しては, 心理的問題を年長児まで持ち越すと 行動化の問題が起こる可能性が高く, 遅くとも小学校中 学年期までに，心理的アプローチが行われるべきである とされている4．われわれがかかわった患者たちも，心 因性難聴をきっかけにADHDとの診断に導かれた例が多 くあり, 耳鼻咽喉科外来が ADHD の早期発見の空口にな りらるものと考えられる.

「葛藤群」の患者は, 甘えたい欲求を抑光, じっくりと 見守られる体験が不足している印象で, 「自分のいらこと を聴いてくれない，自分のことを見てくれない」との思 いを強く抱いている. 彼らは,「聴いてほしい, 見てほし い」といら自分の思いを十分に意識化できず，言葉で訴 えることもできない，その代わりに，身体が「聴こえな い」とのサインを出し, 症状によって周囲の関心を得よ らとする.つまり症状は, 「要求」としての意味を持って いると考えられる.

そこで心理療法においては, 患者の表現や要求を受け 止め, 患者の抱く淋しさや心細さといったさまざまな思 いに心を沿わせつつ，受容的・母性的な見守り体験の場 を提供することが重要となる. その上で, 家庭や学校に おいて患者が安定した人間関係を築くことができるよう 援助していく，その際，一時的な退行現象がみられるこ とも多く，その治療的意味を家族に伝えることも大切で
ある. また家族, とりわけ母親への心理的援助が必要に なってくることも多い.

心因性難聴という症状は，いまだ言葉にならない子ど も達の身体の声, SOS サインであるとわれわれは感じて いる. 治癒耳にも非治癒耳と同程度の, 聴力以外の身体 症状や視覚障害の合併症がみられるとの報告むあり5), 受 け止められなかったサインは, また形を変えて表出して くるものと思われる，そこで，単に身体症状への対処的 治療のみならず，背景にある心理的問題に目を向ける必 要があるとわれわれは考える。 この分類はもちろん大枠 であり，心理療法においてはよりきめ細かな個々に応じ た対応が必要になってくる. 子ども達の身体の声に耳を 傾け，適切な心理的援助がなされることが望まれる.

\section{まとめ}

心因性難聴児を対人関係様式の視点より「他者優先群」 「自己優先群」「葛藤群」の 3 群に分類し, 各群の病態像, 箱庭を示し, 心理的特徵, 望ましい心理療法のあり方に ついて, 臨床心理士の立場から考察した。 対象は耳鼻咽 喉科外来にて心因性難聴と診断された男子 9 名, 女子 22 名で, 年齢は $6 \sim 14$ 歳に分布した. 予後については, 半 年以上心理療法を継続した 19 例のうち, 16 例 (84\%) に 聴力の治癒または改善がみられ，15 例（79\%）に何らか の心理的問題の改善もみられた。

「他者優先群」において, 症状は他者の侵入を防ぐ「守 り」としての意味を持つと考えられ，心理療法において 主体性を育むことが望まれる。「自己優先群」において, 症状は自らを攻撃する他者に対する「拒絶」の意味を持 つと考えられ，素因的問題一の対応と 2 次的心理的問題 への取組みが求められる。「葛藤群」において, 症状は愛 情を求める「要求」としての意味をもつと考えられ，受 容的な見守りのなかで自己表現を促していくことが望ま れる。

本論文の要旨は, 第 64 回耳鼻咽喉科臨床学会において発表し た.

\section{参考文献}

1）日本オージオロジー学会：日本オージオロジー学会用語. Audiology Japan $30: 147 \sim 178,1987$.

2）北尻真一郎, 田㴊圭作, 平海晴一: 心因性難聴の概念. 公 立豊岡病院紀要 $11: 1 \sim 7,1999$.

3）渡辺 純, 前田志寿代, 田中千代, 他 : 小児期の “心因性” 
聴覚障害についての心身医学的考察. 心身医学 $25: 429$ 〜 436, 1985.

4）花熊 暁：ADHD の行動分析. 臨床心理学 $11: 590 \sim 593$, 2002.

5）佐藤 斎, 和田匡史, 土屋乃理子, 他：難聴の自覚のない 小児機能性難聴の検討. 日耳鼻 $101 ： 1390 \sim 1396,1998$.
原稿受付：平成14年11月 22日

原稿採択：平成15月 8 月 13 日

別刷請求先 : 芦谷道子

于572-8551 寝屋川市香里本通町8-45

関西医科大学附属香里病院耳鼻咽喉科 